\title{
A survey of the effectiveness of a telephone-answering service
}

\author{
G. D. MORRISON,* A. J. EVANS,* AND G. P. MCLAUCHLAN† \\ From the *Royal Devon and Exeter Hospital, Wonford, and the $†$ Exeter Health Care District
}

SUMMARY A survey was carried out over a two-year period in Exeter to find out what source of information led patients to attend the local clinic for venereal diseases and to evaluate the effectiveness of a tape-recorded telephone message advertising clinic times. Based on the response from patients it seems difficult to justify the cost of installing a telephone-answering service.

\section{Introduction}

A health care working party on venereal diseases was set up in Exeter in 1974 by the district community physician. The members of the working party consisted of nurses, social workers, the health education officer, the district community physician, and a consultant venereologist. As part of an attempt to improve the service offered by the venereal diseases clinic a tape-recording machine was installed and connected to a direct public telephone line. The telephone number (Exeter 34488) was advertised in the local press in and around Exeter. The population of this area is estimated as 276000 . Shops and offices were offered small posters for display in staff toilets. Larger posters were offered for display in public toilets but this met with resistance. Two local newspapers printed articles which advertised the recorded message but which were more alarming than either informative or accurate.

\section{Material and methods}

The recorded message was kept simple: 'Thank you for ringing. Venereal diseases can only be transmitted by sexual intercourse, so there is no need to worry unless you have had intercourse. If you do have a worry about this, come and see us at the Royal Devon and Exeter Hospital in Barrack Road and ask for the special clinic in the outpatients department. For men, this is on Mondays at $7 \mathrm{pm}$ and Fridays at $2 \mathrm{pm}$. For women, it is on Mondays at $6 \mathrm{pm}$ and Fridays at $3 \mathrm{pm}$. We may find no

Address for reprints: G. D. Morrison, Royal Devon and Exeter Hospital, Barrack Road, Exeter EX2 5DW

Received for publication 20 March 1978 special treatment is needed in your case, but if it should be necessary the condition can be completely cured, and absolutely no one but yourself need ever know you have been to see us. Everything about the visit is completely confidential.' Enough time was allowed at the beginning of the tape-recorded message for a coin to drop in a coin-box telephonethis silence sometimes disconcerted persons using private telephone lines-and the message is repeated once. Apart from a period when the tape broke in the machine, the system has worked well during the period studied. The message was recorded by a member of the hospital staff with a friendly local accent.

The working party thought that some means of measuring the response was needed. Consequently, a meter was fitted to the tape unit to record the number of times the tape was played. Each new patient attending the clinic during the first two years after the tape machine had been installed was given a form asking what source of information led them to attend and listing seven possible answers, one of which was to be indicated. These answers included:

1. Recorded telephone message on Exeter 34488.

2. A doctor's letter or advice.

3. A contact slip.

4. The patient's own initiative.

5. A notice in the public lavatory.

6. A message from a friend (not a contact slip).

7. Other sources, including transferral from another clinic.

\section{Results and comments}

The results for the first two years are shown in Table 1. These results were disappointing as the working party had hoped that the tape-recorded 
Table 1 Numbers of patients attending the clinic in response to seven sources of information

\begin{tabular}{llllllll}
\hline \multicolumn{7}{l}{ Information source } \\
\cline { 2 - 8 } Year & $(1)$ & $(2)$ & $(3)$ & $(4)$ & $(5)$ & (6) & $(7)$ \\
\hline First & 31 & 321 & 108 & 413 & 15 & 53 & 15 \\
Second & 82 & 254 & 90 & 455 & 10 & 66 & 25 \\
\hline
\end{tabular}

(1) Recorded telephone message (2) doctor's letter or advice (3) contact slip (4) patient's own initiative (5) notice in public lavatory (6) message from a friend (7) other sources.

Table 2 Diagnoses of patients* attending the clinic in response to telephone-answering service

\begin{tabular}{|c|c|c|c|c|c|c|c|c|c|c|c|c|c|c|}
\hline \multirow[b]{2}{*}{ Year } & \multicolumn{2}{|c|}{ Gonorrhoea } & \multicolumn{2}{|c|}{ Candidosis } & \multicolumn{2}{|c|}{$\begin{array}{l}\text { Non-specific or } \\
\text { non-gonococcal } \\
\text { urethritis }\end{array}$} & \multicolumn{2}{|c|}{$\begin{array}{l}\text { Other } \\
\text { conditions } \\
\text { (treated) }\end{array}$} & \multicolumn{2}{|c|}{$\begin{array}{l}\text { Other } \\
\text { conditions } \\
\text { (untreated) }\end{array}$} & \multicolumn{2}{|c|}{ Herpesvirus } & \multicolumn{2}{|c|}{ Warts } \\
\hline & Men & Women & Men & Women & Men & Women & Men & Women & Men & Women & Men & Women & Men & Women \\
\hline $\begin{array}{l}\text { First } \\
\text { Second } \\
\text { Total }\end{array}$ & $\begin{array}{r}7 \\
4 \\
11\end{array}$ & $\begin{array}{l}1 \\
3 \\
4\end{array}$ & $\begin{array}{l}1 \\
0 \\
1\end{array}$ & $\begin{array}{l}1 \\
2 \\
3\end{array}$ & $\begin{array}{r}5 \\
19 \\
24\end{array}$ & $\begin{array}{l}2 \\
1 \\
3\end{array}$ & $\begin{array}{r}7 \\
8 \\
15\end{array}$ & $\begin{array}{l}0 \\
5 \\
5\end{array}$ & $\begin{array}{r}5 \\
28 \\
33\end{array}$ & $\begin{array}{r}0 \\
10 \\
10\end{array}$ & $\begin{array}{l}2 \\
1 \\
3\end{array}$ & $\begin{array}{l}\mathbf{0} \\
\mathbf{0} \\
\mathbf{0}\end{array}$ & $\begin{array}{l}1 \\
4 \\
5\end{array}$ & $\begin{array}{l}0 \\
0 \\
0\end{array}$ \\
\hline
\end{tabular}

*One patient had two diagnoses

message would have encouraged more patients to attend the clinic. In the first year there were 4876 telephone calls and in the second year 2979. It is impossible to assess the number of patients reassured by the message or to know on how many occasions the call was frivolous.

The diagnoses of patients attending the clinic as a result of the answering service are shown in Table 2. No case of syphilis or trichomoniasis was seen.

The number of patients with gonorrhoea who attended as a result of the answering service compared with three other sources of information is shown in Table 3.

Table 3 Number of patients with gonorrhoea attending the clinic in response to four sources of information

\begin{tabular}{lcccc}
\hline Year & $\begin{array}{l}\text { Recorded } \\
\text { telephone message }\end{array}$ & $\begin{array}{l}\text { Own } \\
\text { initiative }\end{array}$ & $\begin{array}{l}\text { Contact } \\
\text { slip }\end{array}$ & $\begin{array}{l}\text { Doctor's } \\
\text { letter }\end{array}$ \\
\hline First & 8 & 71 & 45 & 66 \\
Second & 7 & 52 & 41 & 58 \\
Total & 15 & 123 & 86 & 124 \\
\hline
\end{tabular}

From these results it appears that the answering service is not of great value in persuading patients to attend.

The cost of running the answering service for the two years was: $£ 248$ for the rental and installation of the telephone and $£ 351$ for advertising, thus giving a total of $£ 599$. The approximate cost of the service per patient who attended as a result of the answering service was $£ 5.14$. The approximate cost of treatment per patient with gonorrhoea is $£ 40$. It is difficult to justify this expenditure on the basis of the results obtained.

A similar answering service was started in Bristol (telephone Bristol 24416) in 1970, and clinics in Bolton (telephone Bolton 35151) and Sheffield (telephone Sheffield 28778) both have recorded messages telling callers about the clinics. Out of a total of 18886 callers to the Bristol telephone service in the first 21 weeks, 60 men and 81 women said they had attended as a result of hearing the recorded message. Of these, seven men and 14 women had gonorrhoea, 25 men and 41 women needed treatment for other conditions, while 25 men and 26 women required no treatment (Mountford, unpublished data). The Bristol Health Education Department continued to use their tape-recorded message, although the results are no longer being monitored. It may be justifiable to use such a system in a large city, but we do not feel that the results obtained in Exeter justify the expense.

We would like to thank Sisters Lodge and Fitzgerald and Staff Nurse Burbridge for their help in the clinic and Mrs H. J. Campbell for typing the manuscript. 